\title{
Promotion of diversity, inclusion and participation in the rehabilitation process
}

\author{
Christoph Käppler ${ }^{1}$
}

(iD) ORCID: https://orcid.org/0000-0002-3154-3134

\section{Fabiana Faleiros ${ }^{2}$}

(iD) ORCID: http://orcid.org/0000-0003-3723-7944

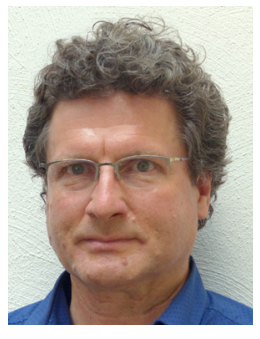

In 1993, speaking about diversity, the then President of the Federal Republic of Germany, Richard von Weizsäcker, made a statement: "It is normal to be different." This is true, we are all different. However, if on the one hand we agree with this undoubted fact and we want to be diverse, unique with the same value and characteristic profile of each one. On the other hand, concomitantly, we tend to want to be equal; a fact that can be observed, for example, in adolescents who have the desire to be or look like members of the same social group (age group, gender, etc.) and, especially, with the preferred models of the generation itself. In this sense, we can verify one of the ambivalences of human life.

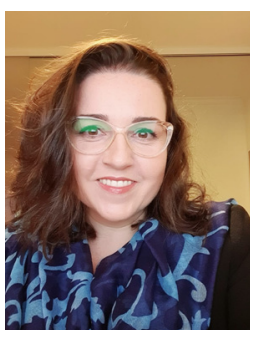

Thus, the challenge arises to guarantee, to each human being, living their own life, as a unique opportunity, according to their own perspectives, visions, desires and (special) needs. The terms equal opportunities, equality, overcoming barriers, accessibility and non-discrimination, are summarized as participation and inclusion in society. These are foundations inherent to human rights and represent aspects of respect and appreciation for human diversity ${ }^{(1)}$, considering the ultimate goal of rehabilitation to achieve and retain the highest possible level of autonomy for social participation(2).

Regarding rehabilitation, the focus is shifting from a biomedical perspective to a personcentered perspective, which is included and a participant in a given society. This shift from understanding perspective to understanding it as social inequality reinforces the idea of difference, not as an individual attribute, but as a result of a society still unprepared for human diversity ${ }^{(1-3)}$. Thus, the promotion of autonomy and participation are, at the same time, fundamental criteria and central objectives of rehabilitation. Conceptions on autonomy vary across individuals and cultures, but a distinction can be made between decision-making autonomy (ability to make

\footnotetext{
${ }^{1}$ Faculdade de Ciências da Reabilitação da Universidade de Dortmund, German.

2 Universidade de São Paulo, Escola de Enfermagem de Ribeirão Preto, PAHO/WHO Collaborating Centre for Nursing Research Development, Ribeirão Preto, SP, Brazil.
}

\section{How to cite this article}

Käppler C, Faleiros F. Promotion of diversity, inclusion and participation in the rehabilitation process. SMAD, Rev Eletrônica Saúde Mental Álcool Drog. 2021;17(1):5-6. doi: https://dx.doi.org/10.11606/issn.1806-6976.smad.2021.000143. 
decisions without external interference) and execution autonomy (ability to act as the individual wishes). Decision-making autonomy can increase throughout life, even while execution autonomy may be declining. While independence represents the person's ability to carry out an activity without assistance, autonomy refers to the ability to think, to choose, and to decide. For authentic participation to exist, it is essential to guarantee, as a prerequisite, sufficient execution autonomy to communicate, and enough decision-making autonomy to be an authentic communicator ${ }^{(2)}$.

In 2004, Community Based Rehabilitation (CBR) was defined and adopted by the main international education and health institutions, including the United Nations Educational, Scientific and Cultural Organization, the World Health Organization and the International Labor Organization. CBR is carried out through the combined efforts of the individuals themselves, their families and communities, and the corresponding health, education, social and labor services ${ }^{(3)}$. It constitutes a community development strategy for rehabilitation, equalization of opportunities and social inclusion(3). Although the concept of rehabilitation is broad, in the practice it does not always include the necessary actions in the social sphere. For example, initiatives to remove barriers in the social sphere, such as adaptations aimed at accessibility in public institutions, are often not considered as part of rehabilitation, although they are essential for its success.

In addition to the socio-cultural aspects, the emotional aspects and the individual's ability to adapt, resilience must be considered as part of the rehabilitation process. In this context, resilience can be understood as an adaptation process that involves a set of thoughts, emotions and actions that can be learned and developed, over time, in response to critical or even traumatic events in life, favoring overcoming, preservation and adaptation of the individual.

Another fundamental aspect for the success of rehabilitation is the inclusion of the person, in addition to the education system ${ }^{(4)}$, in the labor market. Despite the relevance of the return to work, both for financial conditions and for emotional well-being, it is observed that rehabilitation teams do not always train to return to the labor market. In this direction, some methodologies, such as Supported Employment (SE), aim to promote market insertion of people with disabilities, victims of domestic violence, mental illness, ex-drug addicts and long-term unemployed people. SE breaks the barriers created by the traditional models, which conceived these different people as incapable, dependent and unfit for the labor market. It ensures that they are able to participate and actively contribute to society. It promotes access to the rights of competitive employment, education, leisure, within the scope of sport and culture, use of transport and social participation ${ }^{(1-3,5)}$.

Given the above, we reinforce that the rehabilitation process must begin as early as possible, gradually, according to the individual biopsychosocial and family context, seeking to promote autonomy so that authentic participation in society may come to occur.

\section{References}

1. Lei no 13.146, 06 de julho de 2015 (BR). Institui a Lei brasileira de inclusão da pessoa com deficiência (estatuto da pessoa com deficiência). Brasília; 2015. Disponível em: http://www. planalto.gov.br/ccivil_03/_ato2015-2018/2015/ Lei/L13146.htm.

2. Andrade VS de, Faleiros F, Balestrero LM, Romeiro V, Santos CB dos. Social participation and personal autonomy of individuals with spinal cord injury. Rev Bras Enferm. 2019 Feb;72(1):241-7. doi: https://doi.org/10.1590/00347167-2018-0020.

3. Organização Mundial da Saúde. Community Based Rehabilitation: CBR Guidelines. Bruxelas; 2010.

4. Käppler C, Eisenberg R, Eisenberg U, Faleiros F. Auf dem Weg in eine inklusive Lebenswelt. In: Deutsch-Brasilianische Industrie- und Handelskammer São Paulo. Diversität in Brasilien / Diversidade no Brasil. São Paulo: AHK; 2019. p. 92-5. 5. Timm T, Anders W, Eisenberg R, Käppler C. Primeiro Guia Brasil-Alemanha de Inclusão - Viver Diversidade. São Paulo: AHK; 2016. 160 p. 